\title{
Stakeholders and critical factors in the Brazilian government's public private partnerships
}

David Curtinaz Menezes

Universidade de Brasília (UnB)

Valmir Emil Hoffmann

Universidade de Brasilia (UnB)

Helio Zanquetto Filho

Universidade Federal do Espírito Santo (UFES)

This study identifies the relationship between stakeholders and critical success factors in the Brazilian Government Public Private Partnerships (PPPs). We have studied two Brazilian Government PPPs using an exploratory and descriptive qualitative approach. Stakeholders were categorized based on the Mitchell et al. (1997) and Frooman (1999) models. We have showed that i) the models are complementary since some of the most influential stakeholders are also the most powerful; ii) beyond stakeholders and critical factors already mentioned in literature, we have found one new stakeholder (UNDP) and one new critical factor (compliance with recommendations of oversight bodies). This research has a practical contribution as it identifies critical factors associated with the most important stakeholders, enabling decision makers to design a relationship strategy for dealing with such players, taking into account the factors that facilitate or hinder the PPP structuring process.

Key Words: Public Private Partnership, Stakeholders, Critical Factors

[Artigo recebido em 15 de julho de 2019. Aprovado em 15 de agosto de 2019.] 


\section{Stakeholders e fatores críticos em parcerias público privadas do Governo Federal}

Este estudo identifica a relação entre stakeholders e os fatores críticos em Parcerias Público-Privadas (PPPs) do Governo Federal. Foram estudadas duas PPPs usando uma abordagem qualitativa exploratória e descritiva. As partes interessadas foram categorizadas com base nos modelos de Mitchell et al. (1997) e Frooman (1999). Os resultados demostram que: i) os modelos são complementares já que alguns dos stakeholders mais influentes são também os mais poderosos; ii) além dos stakeholders e fatores críticos já mencionados na literatura, encontramos neste estudo um novo ator (PNUD) e um novo fator crítico (atendimento às recomendações dos órgãos de fiscalização). Esta pesquisa tem importância prática, pois identifica fatores críticos associados aos stakeholders mais importantes, permitindo que os tomadores de decisão elaborem uma estratégia de relacionamento para lidar com tais atores, levando em consideração os fatores que facilitam ou dificultam o processo de estruturação da PPP.

Palavras-chave: Parceria Público-Privada, Stakeholders, Fatores Críticos

\section{Stakeholders y factores críticos em las alianzas público privadas del Gobierno Federal}

Este estudio identifica la relación entre los stakeholders y los factores críticos de las Alianzas Público Privadas (PPPs) del Gobierno Federal. Se estudiaron dos PPPs usando un abordaje cualitativo exploratorio y descriptivo. Las partes interesadas se clasificaron según los modelos de Mitchell et al. (1997) y Frooman (1999). Los resultados demuestran que: i) los modelos son complementarios ya que algunos de los stakeholders más influyentes son también los más poderosos; (ii) además de los stakeholders y factores críticos ya mencionados en la literatura, encontramos en este estudio un nuevo actor (PNUD) y um nuevo factor crítico (atención a las recomendaciones de los órganos de fiscalización). Esta investigación tiene importancia práctica, pues identifica factores críticos asociados a los stakeholders más importantes, permitiendo que los tomadores de decisión elaboren una estrategia para lidiar con tales actores, teniendo en cuenta los factores que facilitan o dificultan el proceso de estructuración de la PPP.

Palabras clave: Alianzas Público Privada, Stakeholders, Factores Críticos 


\section{Introduction}

Discussion on Public Private Partnerships (PPPs) dates back to the study of interorganizational relationships (IOR), considering that a PPP brings together different types of players - public and private ones - for the provision of a particular public good or service. PPPs constitute a cooperation form and a management tool (HODGE; GREVE, 2007) used to mobilize and encourage the private sector to participate as financer, builder or operator in projects of public sector interest (CUTRIM; TRISTÃO; TRISTÃO, 2017).

In the literature on IOR, the most prominent studies indicate that certain factors are required for this type of relationship to be successful, such as the work of Jarillo (1988) on the value of the relationship for the parties involved and the savings on transaction costs generated by the relationships; having something to share and contribute to the IOR (POWELL, 1990). All these texts refer to IORs between companies. Thus, it seems important to identify whether these are also critical success factors (CSF) for PPP structuring process.

It is understood that IORs can engage different profiles players, i.e., only private companies (JARILLO, 1988); private companies and third sector, the latter and government or government and private companies (HODGE; GREVE, 2007). Addressing specifically to PPPs, international studies underline factors that range from those of internal nature, such as project quality, to external ones, such as the favorable legal framework.

PPP is comprised of public and private players but there are more players interested in the partnership results. So, they are able to influence decisions, in a clear reference to the Theory of Stakeholder (FREEMAN; REED, 1983). Players in a PPP can be government agencies, concessionaire (private partner), among others. These players may have certain attributes (MITCHELL; AGLE; WOOD, 1997) that allow them to facilitate or hinder the structuring process. In the literature, the two issues, CSFs and stakeholders, appear separately. For example, Thamer and Lazzarini (2015) paper only discuss CSFs. On the other hand, Cabral, Fernandes and Ribeiro (2016) only address PPPs stakeholders.

This study aims to fill that gap, since the literature researched in different bases found no studies addressing the two issues connectedly, CSF and stakeholders. The jointing analysis of the two constructs allows a contribution to stakeholder theory because the critical factors associated with the actors show how the action of these actors can affect specifically the development of a PPP. Thus, this study makes the connection between stakeholders and critical factors for the development of a PPP. Such connection is important because it allows decision makers to devise strategies 
for developing relationships with such players, considering critical success factors associated with them, i.e. aspects that may facilitate or hinder the process of structuring a PPP.

Besides, the importance of the study also stems from the fact that we know little about the performance of public-private partnership projects in Brazil and their constraints (CABRAL; REIS, 2017). In addition, it should be stressed that partnerships between the public and private sectors are a current trend in public administration (CAVAlCANTE, 2019).

In methodological terms, the article was built from the analysis of two Brazilian Government PPPs (multiple case study). We interviewed individuals who participated in the structuring process of these PPPs. Fourteen interviews were conducted with experts from the government bodies, public and private companies and international organizations. From these interviews it was possible to identify CSFs and stakeholders and categorize stakeholders based on the Mitchell et al. (1997) and Frooman (1999) models. The results shows that: i) the models are complementary since some of the most influential stakeholders are also the most powerful; ii) beyond stakeholders and critical factors already mentioned in literature, we have found one new stakeholder (PNUD) and new other critical factor (compliance with recommendations of oversight bodies). These results are relevant to the discussion the role of Stakeholders and CSFs in PPPs in the Federal Government because, for example, they demonstrate peculiarities of Brazilian Government PPPs. In this sense, the uniqueness of UNDP stems from the fact that the federal government used a technical cooperation agreement to hire consultancies for helping PPP projects structuring. The uniqueness of compliance with the recommendations of oversight bodies seems to stem from the pre-bidding process of PPP in the Federal Government in that the approval by BCA is a prerequisite for the completion of PPP structuring.

In addition to this introduction, this article has three more sections. The first presents the theoretical basis that structured the data analysis. The second section describes how the research was developed and presents data analysis results. The third section presents conclusions, research limitations and recommendations for future research.

\section{Literature review}

This section will cover the interface between PPPs and interorganizational cooperation. In addition, this section also includes the concept and identification of stakeholders and the concept of CSF. Furthermore, it addresses stakeholders and 
critical factors found in other PPP studies.

\subsection{Interorganizational cooperation and Public Private Partnership}

PPP has been used since the late 1980s in a context of reduced the presence of the state in the economy (BRITO; SILVEIRA, 2005) and as a way to circumvent the lack of public resources to carry out investments in infrastructure (CUTRIM et al., 2017). The state ceases to act directly in the implementation, providing space for private organizations to provide them. In this context, the private partners employ their expertise and their resources to implement them. Therefore, among other key elements to ensure the effectiveness of the provision of these services are the reputation and the technical expertise of the private partner (BUENO; BRELÀZ; SALINAS, 2016).

In this sense, PPPs is often characterized as a product of the State reform, undertaken in the 1990s, which led to a redefinition of state activities with significant expansion of the area susceptible to partnerships between the public and private sectors. In Brazil, the PPPs started from 2005 after the regulatory framework was created. In this context, countries have begun to adopt changes in the way infrastructure services are provided, fostering the establishment of institutional arrangements for partnerships between the public and private sectors (CABRAL et al., 2016).

However, it should be emphasized that the "PPP does not imply less government, but a different role to be played by it" because, although services are delivered by the private partner, the government continues to be the responsible for setting quality/performance standards and for monitoring service provision (JAMALI, 2004, p. 109).

Thus, it seems that in order to constitute a PPP, the government and the companies involved establish a distinct organizational form, different from their original ones, in a context of cooperation. Therefore, establishment of a PPP requires governments to develop appropriate structures and skills to play this new role (FIRMINO, 2018).

Based on Franco's classification (2007), PPPs can be considered strategic process of interorganizational cooperation. It is because these organizations build partnerships to obtain the resources they need, but do not have (OLIVER, 1990). This seems to be the case with the PPP whereby the public partner seeks to obtain a resource that is not available (private sector expertise to build and run infrastructure facilities) and needs to be aimed at providing a good service to society.

Therefore, this partnership can be explained by the determinants of interorganizational relationships, because, as Oliver (1990) explains, one of the 
reasons that lead organizations to join is access to the resource they do not have. Thus, the determining factor for this partnership is the achievement of efficiency. In this sense, there is empirical evidence of efficiency in PPPs contracts (BRITO; SILVEIRA, 2005). Moreover, they can be classified according to the strategic typology suggested by Franco (2007), since they seek to develop skills, improve the level of innovation and modernization (RODRIGUES; ZUCCO, 2018), decrease operational costs (CABRAL; REIS, 2017) and provide a better quality service (JERGER, 1996).

Another example showing that PPPs are an interorganizational cooperation form lies on the fact that PPPs also meet the criteria described by Silva and Coser (2006), namely, that partners must know their obligations in order to maintain the cooperative relationship. In this sense, the PPP is established under a contract describing all public partner and the concessionaire (private partner) obligations. In fact, this is an important critical factor as we will see later.

\subsection{Stakeholders: definition, identification, and PPP}

Freeman and Reed (1983) suggested two definitions for stakeholder that are still useful. A wide one, which they are any group or individual who can affect and be affected by the development of the organization's activities; and a restricted one, whereby stakeholders are those groups on which the organization depends for survival. These definitions were conceived for private organizations; however, a PPP is a hybrid organizational arrangement as we already point out. For this reason, in this research, the concept of stakeholder should be understood as any group or entity that can affect and/or be affected by the development of a PPP.

In order to identify the stakeholders, it is possible to start from their attributes (MITCHELl et al., 1997), or their ability to retain strategic resources (FROOMAN, 1999). Among their differences, it should be noted that, while the first classifies stakeholders by creating a company's interest ranking as regards their action, the second guides the actions of the company based on understanding how stakeholders can act to fulfill their interests.

The typology of Mitchell et al. (1997) was created considering the following attributes: 1) the power to influence the organization - ability to achieve expected results; 2 ) the legitimacy of the relationship with the organization - widespread perception that the actions of a particular player are desirable or appropriate vis$a$-vis a system of socially constructed norms and values (public interest); and 3) the urgency in meeting their interest - degree to which stakeholder demands immediate organization's managers attention. Thus, by combining these three attributes, the authors suggest that there are seven different types of stakeholders, as shown in Figure 1. 
According to Mitchell et al. (1997), the dormant stakeholder, despite its power, is not used because it lacks legitimacy and urgency. The discretionary stakeholder holds legitimacy, but has no power to influence decision-making and lacks urgency in meeting its interests. The demanding has only urgency and needs to join a stakeholder who holds power or legitimacy to attract the attention of managers.

The dominant influences decision-making because it has power and legitimacy and, in general, develops formal mechanisms, e.g., participation on the board to ensure the importance of their relationship with the firm. The dependent has urgency and legitimacy, however, has no power, and depends on another player to achieve its goals.

The dangerous has power and urgency and receives this name because it uses coercion and violence to try to achieve its goals, and as such should be monitored closely. The dependent should also be monitored, as it can draw power from another stakeholder to have its demands met. The definitive stakeholder is the most important stakeholder because it has power, legitimacy and urgency, which draw immediate and priority attention to this player. The dominating coalition in an organization tends to be composed of dominant and definitive players (Mitchell et al., 1997).

\section{Figure 1 - Classes of Stakeholders}

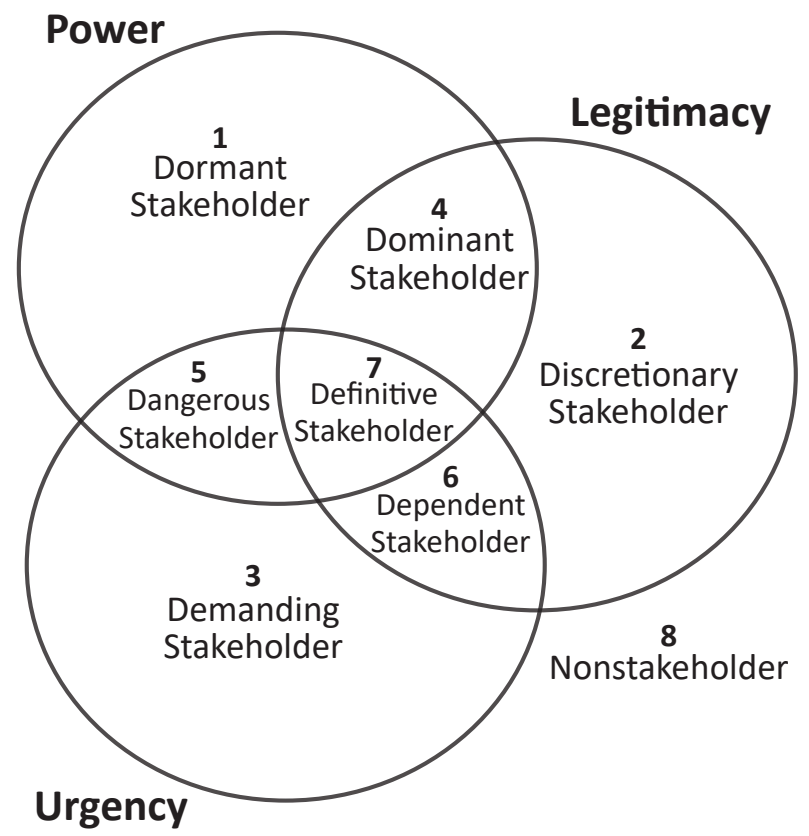

Source: Mitchell et al. (1997, p. 874). 
Frooman (1999) developed an analysis method about the strategies that can be used by stakeholders to influence to organizations decision-making process, based on the Resource Dependency Theory. For the author, four strategies are applied by stakeholders: i) direct retention; ii) direct use; iii) indirect retention and iv) indirect use.

Resource retention strategies are "those in which there is a discontinuity in resource transfer by the stakeholder to the firm, with the intention of promoting a change in organization behavior" (FROOMAN, 1999, p. 196). In strategies of use, the stakeholder continues providing resources, but under certain conditions.

These strategies are complemented by the direct strategy, when the stakeholder manipulates the resource flow to the firm, and the indirect strategy, by which the stakeholder, lacking control over the resource, exerts influence through an ally that manipulates the resource flow. Based on them, Frooman (1999) established four types of relationships between organization and stakeholder: firm power, high interdependence, low interdependence, and stakeholder power.

Finally, it should be noted that literature has identified several PPP's stakeholders including public agencies, responsible for the preparation and implementation of PPPs, financier, consultants, citizens, as users of PPP services, concessionaire companies that play the role of private partners - and oversight bodies.

\subsection{Critical factors for PPP success}

International literature has identified certain critical factors for the PPPs success, which are described by Ismail $(2013$, p. 8) as being "the areas where obtaining favorable results is essential for managers to achieve goals". These critical factors can help to increase the attractiveness of PPP Project or hinder the structuring process because of that they can be classified in positive and negative factors (HWANG; ZHAO; GAY, 2013). Figure 2 summarizes these factors. 
Figure 2 - Critical factors identified

\begin{tabular}{|c|c|c|}
\hline Kind of Factor & Critical Factors & Papers \\
\hline \multirow{3}{*}{ Positive } & $\begin{array}{l}\text { Appropriate risk } \\
\text { allocation }\end{array}$ & $\begin{array}{l}\text { Hwang et al. (2013); Queiroz, } \\
\text { Astesiano and Serebrisky (2014); Kyei } \\
\text { and Chan (2015). }\end{array}$ \\
\hline & Institutional apparatus & $\begin{array}{l}\text { Hwang et al. (2013); Queiroz et al. } \\
\text { (2014); Weiermair, Peters and Frehse } \\
\text { (2008); Jamali (2004); Ismail (2013); } \\
\text { Jacobson and Choi (2008) and Liu and } \\
\text { Wilkinson (2014); Firmino (2018) }\end{array}$ \\
\hline & Project quality & $\begin{array}{l}\text { Hwang et al. (2013); Queiroz et al. } \\
\text { (2014); Weiermair et al. (2008); } \\
\text { Jamali (2004); Liu and Wilkinson } \\
\text { (2014); Firmino (2018). }\end{array}$ \\
\hline \multirow{9}{*}{ Positive } & $\begin{array}{l}\text { Favorable economic } \\
\text { environment }\end{array}$ & Ismail (2013); Kyei and Chan (2015). \\
\hline & $\begin{array}{l}\text { Competitive bidding } \\
\text { process }\end{array}$ & Firmino (2018) \\
\hline & $\begin{array}{l}\text { Favorable regulatory } \\
\text { framework }\end{array}$ & $\begin{array}{l}\text { Hwang et al. (2013); Ismail (2013); } \\
\text { Sabry (2015); Kyei and Chan (2015). }\end{array}$ \\
\hline & $\begin{array}{l}\text { Compatibility between } \\
\text { partners' expectations }\end{array}$ & Jamali (2004) \\
\hline & $\begin{array}{l}\text { Commitment of top tier } \\
\text { government managers }\end{array}$ & $\begin{array}{l}\text { Weiermair et al. (2008); Jacobson and } \\
\text { Choi (2008) }\end{array}$ \\
\hline & $\begin{array}{l}\text { PPP entrepreneurial } \\
\text { culture }\end{array}$ & $\begin{array}{l}\text { Weiermair et al. (2008); Cutrim et al. } \\
\text { (2017) }\end{array}$ \\
\hline & Partners' commitment & $\begin{array}{l}\text { Ismail (2013); Jacobson and Choi } \\
\text { (2008); Kyei and Chan (2015). }\end{array}$ \\
\hline & Popular support & Kyei and Chan (2015); Firmino (2018) \\
\hline & $\begin{array}{l}\text { Adequate } \\
\text { communication with } \\
\text { stakeholders }\end{array}$ & $\begin{array}{l}\text { Weiermar et al. (2008); Kyei and } \\
\text { Chan (2015). }\end{array}$ \\
\hline
\end{tabular}




\begin{tabular}{|c|c|c|}
\hline Kind of Factor & Critical Factors & Papers \\
\hline \multirow{6}{*}{ Negative } & Political risk & \multirow{2}{*}{ Cutrim et al. (2017) } \\
\hline & Legal risk & \\
\hline & $\begin{array}{l}\text { Environmental } \\
\text { restrictions or } \\
\text { Environmental impact of } \\
\text { project }\end{array}$ & $\begin{array}{l}\text { Kyei and Chan (2015); Cutrim et al. } \\
\text { (2017). }\end{array}$ \\
\hline & $\begin{array}{l}\text { Difficulty in obtaining } \\
\text { bank financing }\end{array}$ & Cutrim et al. (2017) \\
\hline & Budget Constraints & $\begin{array}{l}\text { Azevedo and Azevedo (2017); Morales } \\
\text { and Tagle (2017); Nose (2017). }\end{array}$ \\
\hline & $\begin{array}{l}\text { Lack of institutional } \\
\text { apparatus }\end{array}$ & Cutrim et al. (2017) \\
\hline
\end{tabular}

Source: Authors.

These factors are considered critical to the success of PPPs and affects the viability of PPPs. For example, an appropriate regulatory framework along with economic conditions define the choices available to firms and their production costs. Thus, they impact on their profitability and the viability of their business (NORTH, 1991).

Another example is the budget constraint which is a critical factor because the remuneration of the private partner has a dependency of the public entity considering that the remuneration of the private derives from some combination of government payments and user fees (MASKIN; TIROLE, 2008). In the Brazilian case, this dependence is even greater, since there is a possibility that the private partner's revenue will be entirely due to the payment made by the government (MORAES; TAGLE, 2017). In this sense, a poor fiscal situation may be an indication that the public partner is unable to support the project (AZEVEDo; AZEVEDO, 2017). Furthermore, it should be emphasized that the weakness in governments' fiscal institutions can undermine the quality of project selection, increases contract disputes of PPPs and increasing government's probability to give guarantees as a way to attract the private partner (NOSE, 2017). Therefore, the budget constraint can be classified as a factor that may hinder PPP implementation.

\section{Method}

This is a qualitative approach research, with transversal cut, by a multiple case study. The case study is very common on the PPP research as it is possible to see in Cabral et al. (2016). 
Cases studied. We have studied two Brazilian government PPPs: a) Military High School of Manaus (MSM) - is a PPP that aims at the construction and operation of a high school in Manaus with a capacity of about 1500 students. The term of the contract is 25 years.; b) Physical Education Center Admiral Adalberto Nunes (PECAN) - is a PPP that aims to implement the infrastructure, operation and maintenance of a sports complex of the Navy located in the city of Rio de Janeiro. The term of the contract is 25 years.

To select theses PPP we have considered the following reasons: i) Cabral et al. (2016) said the more advanced the PPP, the better the analysis of the influence of the stakeholders throughout the PPP life cycle. And besides there are a high amount of PPP projects that are started but are not concluded. For example, in 2017, 281 PPPs projects were initiated, but only 3 were successful and had signed contracts (MÁxıMO, 2017). That's why we have chosen two PPPs that were in more advanced stages when the present study was performed.; ii) The cases we have studied refer to the two first PPPs projects of the Brazilian military forces.

Data collection. We interviewed individuals who participated in the structuring process of these PPPs, and who were involved for at least six months in the projects. Interviews were conducted between May to July 2014. The average duration of interviews was about 40 minutes. The interviews were recorded and transcribed. The interviewees who were in Brasilia were interviewed face to face and the others were interviewed by telephone.

Each participant was asked who would be the stakeholders in the process of structuring the PPPs studied. It is noteworthy that before the interview, participants were presented with the broad concept of stakeholder according to Freeman and Reed (1983). In addition, a form was developed from Falqueto, Hoffmann and Gomes (2013) which was based on Mitchell et al. (1997). A five-point Likert scale - 1 represents full disagreement and 5 represents full agreement - was used to numerically represent respondents' perceptions of power, legitimacy and urgency to each stakeholder (Table 1).

Table 1 - Form based on Mitchell et al. (1997)

\begin{tabular}{|c|c|c|c|c|c|c|c|c|c|c|c|c|c|c|c|}
\hline \multirow[t]{2}{*}{ Stakeholder } & \multicolumn{5}{|c|}{$\begin{array}{l}\text { Does this stakeholder } \\
\text { has the power to } \\
\text { influence decision } \\
\text { making to structure } \\
\text { a PPP? }\end{array}$} & \multicolumn{5}{|c|}{$\begin{array}{l}\text { Are the requests } \\
\text { of this stakeholder } \\
\text { legitimate? }\end{array}$} & \multicolumn{5}{|c|}{$\begin{array}{l}\text { Does the } \\
\text { organization give } \\
\text { priority (urgency) } \\
\text { to this stakeholder } \\
\text { requests? }\end{array}$} \\
\hline & 1 & 2 & 3 & 4 & 5 & 1 & 2 & 3 & 4 & 5 & 1 & 2 & 3 & 4 & 5 \\
\hline $\begin{array}{l}\text { Stakeholder } \\
\mathrm{n}\end{array}$ & & & & & & & & & & & & & & & \\
\hline
\end{tabular}


Table 3 - information about the interviewees

\begin{tabular}{|c|c|c|c|}
\hline Interviewee & PPP & Entity & Position \\
\hline E1 & \multirow{5}{*}{ MSM } & Army & Colonel \\
\hline E2 & & PPP Unit & Manager \\
\hline E6 & & $\begin{array}{l}\text { Consulting firms specialized in economic } \\
\text { studies }\end{array}$ & Manager \\
\hline E3 & & $\begin{array}{l}\text { consulting firms specialized in engineering } \\
\text { studies }\end{array}$ & Manager \\
\hline E4 & & law firm & Lawyer \\
\hline E10 & \multirow{5}{*}{ PECAN } & $\begin{array}{l}\text { consulting firms specialized in engineering } \\
\text { studies }\end{array}$ & Engineer \\
\hline E14 & & Navy & Captain \\
\hline E13 & & $\begin{array}{l}\text { Consulting firms specialized in economic } \\
\text { studies }\end{array}$ & Manager \\
\hline E8 & & Law firm & Lawyer \\
\hline E7 & & PPP Unit & $\begin{array}{l}\text { Technical } \\
\text { Advisor }\end{array}$ \\
\hline E11 & \multirow{4}{*}{$\begin{array}{l}\text { MSM } \\
\text { and } \\
\text { PECAN }\end{array}$} & $\begin{array}{l}\text { Brazilian General Controller Office - Internal } \\
\text { Control }\end{array}$ & Auditor \\
\hline E5 & & BNDES & Economist \\
\hline E9 & & UNDP & Manager \\
\hline E12 & & Brazilian Court of Auditors - External Control & Auditor \\
\hline
\end{tabular}

Source: Authors.

Data Processing. The stakeholders mentioned by at least two informants were selected and classified as internal or external (economic and political). Internal factors may include, among others, employees. The economic stakeholders include consumers (PPP users) and suppliers. Political stakeholders include, for example, federal government bodies, legislative bodies and regulatory agencies.

The stakeholders' power of influence was established based on the form described in Table 1. Since the form was completed by fourteen respondents, the following indicators were determined: i) more than seven answers in 1 and 2 or in 4 and 5: the majority of participants has a position for or against the statement presented; ii) more than seven answers in 3: it is not possible to draw inferences, since most of the participants neither agree nor disagree with the statement. 
Regarding the identification of critical success factors, all CSFs mentioned by the informants were selected. The aforementioned factors were grouped, taking into account their semantics in order to identify the connections between stakeholders and CSF, a list of the identified stakeholders was presented for the interviewee to connect them to the critical factors. So, reasons for the connections were raised.

\section{Results}

\subsection{Identification of stakeholders}

Stakeholders mentioned during the interviews were compared with those found in the literature review. Results are described in Figure 3. In the column "Stakeholders identified" we highlighted (in bold) those that were not backed by the literature review. Figure 3 shows that a specific stakeholder to PPPs carried out in the case studies is UNDP. The singularity of UNDP stems from the fact that the Brazilian federal government used a technical cooperation agreement to have UNDP assistance to structure PPP projects.

Figure 3 - Comparative table of identified stakeholders

\begin{tabular}{lll}
$\begin{array}{l}\text { Stakeholder Literature } \\
\text { Review }\end{array}$ & $\begin{array}{l}\text { Authors that identified } \\
\text { stakeholder }\end{array}$ & $\begin{array}{l}\text { Stakeholders } \\
\text { identified in the } \\
\text { study }\end{array}$ \\
\hline $\begin{array}{l}\text { Public bodies responsible } \\
\text { for the preparation and } \\
\text { implementation of PPPs }\end{array}$ & $\begin{array}{l}\text { Cutrim et al. (2017); Queiroz et } \\
\text { al. (2014); Cabral et al. (2016). }\end{array}$ & $\begin{array}{l}\text { Ministry of Finance; } \\
\text { Ministry of Planning; } \\
\text { Chief of Staff; Army; } \\
\text { Navy }\end{array}$ \\
\hline Consumers & $\begin{array}{l}\text { Schepper, Dooms and } \\
\text { Haezendonck (2014) }\end{array}$ & Users \\
\hline Citizens & Gomes (2004) & Local society \\
\hline Consultancy & $\begin{array}{l}\text { Cutrim et al. (2017); Queiroz et } \\
\text { al. (2014); Cabral et al. (2016). }\end{array}$ & Consultancies \\
\hline $\begin{array}{l}\text { PPP Management } \\
\text { Committee }- \text { PMC }\end{array}$ & Cabral et al. (2016) & $\begin{array}{l}\text { PPP Management } \\
\text { Committee }- \text { PMC }\end{array}$ \\
\hline Oversight bodies & $\begin{array}{l}\text { Gomes (2004); Cabral et al. } \\
\text { (2016). }\end{array}$ & Oversight bodies \\
\hline Financier & $\begin{array}{l}\text { Cutrim et al. (2017); Schepper } \\
\text { et al. (2014); Queiroz et al. } \\
\text { (2014); Cabral et al. (2016). }\end{array}$ & Financiers \\
\hline
\end{tabular}




\begin{tabular}{lll}
$\begin{array}{l}\text { Stakeholder Literature } \\
\text { Review }\end{array}$ & $\begin{array}{l}\text { Authors that identified } \\
\text { stakeholder }\end{array}$ & $\begin{array}{l}\text { Stakeholders } \\
\text { identified in the } \\
\text { study }\end{array}$ \\
\hline Media & Gomes (2004) & Media \\
\hline Local authorities & $\begin{array}{l}\text { Cutrim et al. (2017); Gomes } \\
\text { (2004) }\end{array}$ & $\begin{array}{l}\text { Local public bodies } \\
\text { and local authorities }\end{array}$ \\
\hline Concessionaire & $\begin{array}{l}\text { Schepper et al. (2014); Queiroz } \\
\text { et al. (2014); Cabral et al. } \\
\text { (2016). }\end{array}$ & Concessionaire \\
\hline - & - & UNDP \\
\hline $\begin{array}{l}\text { Suppliers } \\
\text { Source: Authors. }\end{array}$ & Schepper et al. (2014) & Suppliers \\
\hline
\end{tabular}

The stakeholders were classified assuming the Brazilian federal government to be the organization that is the object of the study. So, we propose three categories: internal, political and Economic. This is an adaptation of the typology proposed by Freeman (1984) which classified the stakeholders in internal and external. According to Freeman (1984), internal stakeholders are responsible for achieving the goals of the organization, such as employees. The external ones are those affected by the performance of the organization, but that do not participate in the organizational project as it is the case of users.

The adaptation of the typology proposed by Freeman (1984) was made because we noticed that the internal and external categories comprise within them stakeholders that have distinct characteristics and that, therefore, can be segmented. In this sense, for example, the bodies of the federal executive branch were classified as internal stakeholders and divided into two subcategories: back office and core business.

The first subcategory includes players who, although involved in the structuring process, are not part of the administrative structure responsible for implementing the project (Ministries of Finance and Planning and direct advisors of the President - Chief of Staff). They are important players because they take part on PMC and establish budgetary (Ministry of Planning) and financial (Ministry of Finance) guidelines. The second subcategory consists of those responsible for implementing and managing the project (Navy and Army).

The other categories refer to external stakeholders according to the typology of freeman (1984). In this way, the category of political stakeholder includes players 
that have their own attributions as legislative bodies and/or regulatory agencies. This is the case of environmental agencies, local public bodies and authorities, as well as the BCA, which also plays the role of legislative body with respect to federal PPPs (Normative Instruction n. 81/2018). Also included in this category are players that are not federal public bodies and do not perform functions directly related to the attributions of the private partner.

However, these players have different functions in the studied PPP projects and so were classified in the following subcategories: supporters of the structuring process, social control agents and local authorities. In the first subcategory are those players that, while not integrating the federal government, provide support in the process of structuring a PPP, namely the consultants and the UNDP, which assist in the relationship between the federal government and the consultants.

The second subcategory includes the media and oversight bodies that, through their activities, provide information that promotes effective social control of PPP projects. The last subcategory includes local public bodies and authorities such as environmental agencies that are players in the structuring process, since they generate municipal regulations on topics such as taxation and environmental guidelines, which must be considered when structuring a PPP.

The category of economic stakeholder comprises project users, as suggested by Freeman and Reed (1983). Moreover, this category included stakeholders that do not have administrative ties with the Brazilian government and that perform functions relating to the attributions of the private partner. Thus, the identified stakeholders were classified according to Figure 4.

Figure 4 - Stakeholders identified

\begin{tabular}{ll}
\hline Categories & Stakeholders \\
\hline & 1) Ministry of Finance \\
Internal - Back office & 2) Ministry of Planning \\
& 3) Chief of Staff \\
\hline Internal - Core business & 4) PMC \\
\hline Political - Auxiliary & 5) Army \\
\hline
\end{tabular}




\begin{tabular}{ll}
\hline Categories & Stakeholders \\
\hline Political - Social Control & 9) Media \\
\hline Political -Local Authorities & Oversight body \\
\hline Economic & Local public bodies and authorities \\
& Users \\
Source: Authors. & Concessionaire \\
\hline
\end{tabular}

\subsection{Critical success factors identified}

The critical factors pointed out during the interviews were compared to the literature review, with column "CSF identified in the study" in Figure 5 highlighting (in bold) those that appear to be specific to the PPPs analyzed here. In addition, the identified critical success factors were classified into the following categories: political, administrative, environmental, cultural, economic and regulatory.

The political category has factors referring to the project's compliance with the guidelines from the top tier of government. The administrative category includes factors that are related to the work developed by government technical staff and the administrative structure of the bodies responsible for the structuring of PPPs. The environmental category covers the factor related to compliance with the environmental guidelines applicable to the project. Cultural factors are that one with relationship between the partners and the convergence of their interests. The economic category refers to factors according to the economic situation. Finally, the regulatory category covers aspects related to the project's regulation (legislation and supervisory structure).

Figure 5 - CSFs identified

\begin{tabular}{|c|c|c|c|c|}
\hline Category & $\begin{array}{l}\text { Type of } \\
\text { CSF }\end{array}$ & $\begin{array}{l}\text { CSF Literature } \\
\text { Review }\end{array}$ & $\begin{array}{l}\text { Authors that have } \\
\text { identified CSF }\end{array}$ & $\begin{array}{l}\text { CSFs identified in } \\
\text { this study }\end{array}$ \\
\hline \multirow[t]{2}{*}{ Political } & Positive & $\begin{array}{l}\text { Commitment } \\
\text { of high-ranking } \\
\text { public managers or } \\
\text { political support }\end{array}$ & $\begin{array}{l}\text { Weiermair et al. } \\
\text { (2008); Jacobson and } \\
\text { Choi (2008); Kyei } \\
\text { and Chan (2015). }\end{array}$ & Political interest \\
\hline & Negative & Political risk & Cutrim et al. (2017); & Political risk \\
\hline
\end{tabular}




\begin{tabular}{|c|c|c|c|c|}
\hline Category & $\begin{array}{l}\text { Type of } \\
\text { CSF }\end{array}$ & $\begin{array}{l}\text { CSF Literature } \\
\text { Review }\end{array}$ & $\begin{array}{l}\text { Authors that have } \\
\text { identified CSF }\end{array}$ & $\begin{array}{l}\text { CSFs identified in } \\
\text { this study }\end{array}$ \\
\hline Administrative & Positive & $\begin{array}{l}\text { Institutional } \\
\text { apparatus (Well } \\
\text { organized and } \\
\text { committed public } \\
\text { agency and good } \\
\text { governance) }\end{array}$ & $\begin{array}{l}\text { Brito and Silveira } \\
\text { (2005); Hwang et al. } \\
\text { (2013); Queiroz et al. } \\
\text { (2014); Weiermair } \\
\text { et al. (2008); Jamali } \\
\text { (2004); Ismail } \\
\text { (2013); Jacobson } \\
\text { and Choi (2008); Liu } \\
\text { e Wilkinson (2014); } \\
\text { Kyei and Chan } \\
\text { (2015). }\end{array}$ & $\begin{array}{l}\text { Institutional } \\
\text { apparatus }\end{array}$ \\
\hline \multirow{7}{*}{ Adminis-trative } & \multirow{7}{*}{ Positive } & Project quality & $\begin{array}{l}\text { Hwang et al. (2013); } \\
\text { Queiroz et al. } \\
\text { (2014); Weiermair } \\
\text { et al. (2008); Jamali } \\
\text { (2004); Liu, Wang } \\
\text { and Wilkinson (2016) }\end{array}$ & Project quality \\
\hline & & $\begin{array}{l}\text { Appropriate risk } \\
\text { allocation }\end{array}$ & $\begin{array}{l}\text { Brito and Silveira } \\
\text { (2005); Hwang et al. } \\
\text { (2013); Queiroz et } \\
\text { al. (2014); Kyei and } \\
\text { Chan (2015). }\end{array}$ & $\begin{array}{l}\text { Appropriate risk } \\
\text { allocation }\end{array}$ \\
\hline & & $\begin{array}{l}\text { Good feasibility } \\
\text { studies }\end{array}$ & Kyei and Chan (2015) & $\begin{array}{l}\text { Prior analysis of } \\
\text { Project costs and } \\
\text { benefits }\end{array}$ \\
\hline & & $\begin{array}{l}\text { Clarity of roles and } \\
\text { responsibilities } \\
\text { among }\end{array}$ & Kyei and Chan (2015) & $\begin{array}{l}\text { Well-drafted } \\
\text { contract }\end{array}$ \\
\hline & & Parties & & \\
\hline & & - & - & $\begin{array}{l}\text { Compliance with } \\
\text { recommendations } \\
\text { of oversight } \\
\text { bodies }\end{array}$ \\
\hline & & $\begin{array}{l}\text { Government } \\
\text { providing } \\
\text { guarantees }\end{array}$ & $\begin{array}{l}\text { Brito and Silveira } \\
\text { (2005); Kyei and } \\
\text { Chan (2015) }\end{array}$ & $\begin{array}{l}\text { guarantees to } \\
\text { public sector } \\
\text { payment }\end{array}$ \\
\hline
\end{tabular}




\begin{tabular}{|c|c|c|c|c|}
\hline Category & $\begin{array}{l}\text { Type of } \\
\text { CSF }\end{array}$ & $\begin{array}{l}\text { CSF Literature } \\
\text { Review }\end{array}$ & $\begin{array}{l}\text { Authors that have } \\
\text { identified CSF }\end{array}$ & $\begin{array}{l}\text { CSFs identified in } \\
\text { this study }\end{array}$ \\
\hline Regulatory & Positive & $\begin{array}{l}\text { Appropriate } \\
\text { or favorable or } \\
\text { good regulatory } \\
\text { framework }\end{array}$ & $\begin{array}{l}\text { Brito and Silveira } \\
\text { (2005); Hwang et al. } \\
\text { (2013); Ismail (2013); } \\
\text { Kyei and Chan } \\
\text { (2015); Sabry (2015). }\end{array}$ & $\begin{array}{l}\text { Appropriate } \\
\text { regulatory } \\
\text { framework }\end{array}$ \\
\hline \multirow{3}{*}{ Cultural } & \multirow{3}{*}{ Positive } & $\begin{array}{l}\text { PPP } \\
\text { entrepreneurial } \\
\text { culture }\end{array}$ & $\begin{array}{l}\text { Weiermair et al. } \\
\text { (2008); Cutrim et al. } \\
\text { (2017) }\end{array}$ & $\begin{array}{l}\text { Existence of an } \\
\text { entrepreneurial } \\
\text { culture with PPP }\end{array}$ \\
\hline & & $\begin{array}{l}\text { Commitment by } \\
\text { both parties }\end{array}$ & $\begin{array}{l}\text { Ismail (2013); } \\
\text { Jacobson and Choi } \\
\text { (2008); Kyei and } \\
\text { Chan (2015). }\end{array}$ & $\begin{array}{l}\text { Commitment } \\
\text { between partners }\end{array}$ \\
\hline & & $\begin{array}{l}\text { Compatibility } \\
\text { between partners' } \\
\text { expectations }\end{array}$ & Jamali (2004) & $\begin{array}{l}\text { Compatibility } \\
\text { between partners' } \\
\text { expectations }\end{array}$ \\
\hline \multirow[t]{2}{*}{ Economic } & Positive & $\begin{array}{l}\text { Favorable } \\
\text { economic } \\
\text { environment or } \\
\text { Sound economic } \\
\text { policy }\end{array}$ & $\begin{array}{l}\text { Ismail (2013); Kyei } \\
\text { and Chan (2015). }\end{array}$ & $\begin{array}{l}\text { Favorable } \\
\text { economic } \\
\text { environment }\end{array}$ \\
\hline & Negative & $\begin{array}{l}\text { Budgetary } \\
\text { Constraints }\end{array}$ & $\begin{array}{l}\text { Azevedo and } \\
\text { Azevedo (2017); } \\
\text { Morales and Tagle } \\
\text { (2017); Nose (2017). }\end{array}$ & $\begin{array}{l}\text { Budgetary } \\
\text { restrictions }\end{array}$ \\
\hline Environ-mental & Negative & $\begin{array}{l}\text { Environmental } \\
\text { restrictions or } \\
\text { Environmental } \\
\text { impact of project }\end{array}$ & $\begin{array}{l}\text { Kyei and Chan } \\
\text { (2015); Cutrim et al. } \\
\text { (2017). }\end{array}$ & $\begin{array}{l}\text { Environmental } \\
\text { restrictions }\end{array}$ \\
\hline
\end{tabular}

Source: Authors.

Figure 5 shows that some CSFs that have been described in the literature have also emerged in this study. Thus, for example, the importance of the regulatory framework which importance is highlighted by the interviewee E5 who states that "if the regulatory part and the contract are not clear, the project will not be implemented or if it is implemented, it will generate a lot of conflicts that will not make it successful". In this sense, private investment in PPP is encouraged by the presence of a sound regulatory framework (SABRY, 2015) because it confers legal protection in the form of enforcement of contracts (PONGSIRI, 2002). Project quality 
appears as important due to the needing for a definition of the project's scope and objectives (HWANG et al., 2013).

The institutional apparatus seems relevant, among the other reasons, because it is necessary to have a governance structure to project (CUTRIM et al., 2017). Note that cooperation demands coordination efforts because PPPs are formed by partners with their own management cultures and practices. Therefore, as noted by Wegner and Padula (2012), monitoring expectations and to what extent they remain aligned as the partnership progresses is important to maintain the parties' interest in collaborating.

Commitment between the partners and compatibility between their expectations constitute a CSF, because it is one of the most important factors in the establishment and maintenance of an inter-organizational relationship (CASTRO; BULGACOV; HOFFMANN, 2011). In this sense, the success of the provision of this service will depend on the relationship build between the public and private partners (BUENO; BRELÀZ; SALINAS, 2016).

The relevance of such a commitment with respect to the public partner is related to political interest since the commitment of this partner will match that of the top management in carrying out and aligning the project with the relevant public policy (WEIERMAIR et al., 2008).

The appropriate allocation of risk to the partner that is best able to manage it appears to be important for a PPP since it allows reduction of costs and uncertainty. The reduction of the uncertainty found in the environment in which the partners operate by reducing costs and risks is one of the main objectives of strategic cooperation (FRANCO, 2007) such as PPPs (BRITO; SILVEIRA, 2005). The existence of budget restrictions is a critical factor as explained by the interviewee (E8), because "it can make the implementation of a PPP unfeasible".

A new factor that has not yet been found in the literature was mentioned in this study: compliance with the recommendations of oversight bodies. It seems to stem from the singularity of the pre-bidding process of a PPP in the federal government in that the approval by BCA is a prerequisite for the completion of PPP structuring.

\subsection{Connection between critical factors and stakeholders}

In this section we describe connections between the most important stakeholders and the critical factors related to them. We have expected the most relevant factors are those related these stakeholders.

Political interest was associated with the Navy and the Army. In this sense, the project must have the commitment of the top management tier of the Navy and of 
the Army. This commitment is important, given that, as the E14 interviewee points out, "the Marine Corps Commander is a General Officer who belongs to the top naval administration. So if this senior management has a project in his area and is not committed to this project, he can stop the project at any stage".

This factor was also associated with the Ministries of Finance and Planning as they are part of the PMC, which is responsible for the analysis and authorization for the project. So, the project must aligned with the respective public policy of the federal government. If the project is not aligned with it, there will be no political interest to promote it. In other words, as the interviewee E5 pointed out, "if the government has no interest in executing the project, it will not happen". In the same sense, the relation between the PMC and the political interest was pointed out, because, as stated by the interviewee E2, "given its composition, the CGP mirrors the political will".

Another connection concerns the institutional apparatus that was associated with the Army and the Navy. Both military forces have a unit dedicated to structuring the project and a trained sectoral body to regulate and supervise the project implementation. In this sense, according to the interviewed E2, "in function of the elaboration of the project, the Army structured the PPP unit". The interviewee E14, when talking about the PPP of PECAN, points out that "the existence of experts to analyze the project is fundamental so that the Navy can leave reflected in the studies, the desire related to the project that is expected to develop".

The institutional framework was also related to the Ministry of Planning. This Ministry was involved in: i) the governance process of the project's structure; ii) technical discussions with consultants; and iii) generating training on PPP for municipal, state and federal civil servants. It should be emphasized that international experience show that is important to have a central public body responsible for coordinate project implementation, develop PPP expertise and disseminate it to other public bodies (BRITO; SILVEIRA, 2005).

Project quality was linked to the Army, Navy and the Ministries of Finance and Planning in terms of their role in defining the project's scope and business model. This factor was related to the Ministries of Finance and Planning since, as E7 interviewer reported, "such ministries have the power to influence the business model of the project". Another reason to associate project quality with such federal government bodies is that, as E12 respondents argue, "these stakeholders have to be concerned about failures in the preparation of the Technical, Economic and Environmental studies".

A well-drafted contract was linked to federal bodies related to the project because it is expected that these stakeholders will avoid the occurrence of 
problems in the project's modeling. In this sense, as E12 interviewer reported, "these stakeholders have to be concerned with inconsistencies in the obligations document, inconsistencies in performance indicators and failures in risk allocation."

Although the existence of an adequate regulatory framework has been attributed to the federal government bodies related to the project, such connection must be attributed to the Ministries of Finance and Planning, since neither the Navy nor the Army participate in discussions on alterations to the regulatory framework of federal PPPs. The importance of the theme is also highlighted by the interviewee E5 when he affirms that "if the regulatory part and the contract are not clear, the project will either be implemented or if it is implemented it will generate a lot of conflicts that will not make it successful".

The budgetary restriction factor was related to the Ministries of Planning and Finance due to the involvement of the former in the preparation of the Federal Budget, and the former's role in the financial availability of credits provided for in the Federal Budget. Compliance with the recommendations of oversight bodies was related to the Navy and the Army, given that they were the responsible bodies for submitting the project to prior approval by BCA.

Environmental restrictions and the lack of a competitive bidding process were associated with the Ministry of Planning (PPP unit), the Navy and the Army because these actors had know-how from their participation in several PPPs before. In this sense, as E12 respondent explains, "I consider that these risk factors are associated with the Unit of PPP because it holds know-how and knowledge because it participates across multiple PPPs. These are items she should be aware of when coordinating with the sector ministry".

Other factors associated with the major stakeholders were the existence of an entrepreneurial culture of PPPs, appropriate risk allocation, compatibility between the expectations of partners and commitment between the partners. However, it should be stressed that only the first factor was associated with all key stakeholders (Figure 6).

In relation to the existence of an entrepreneurial culture of PPPs, it should be emphasized that the existence of an entrepreneurial culture with PPP, as affirmed by interviewee E6, refers "not only to the government, but also to the concessionaire, financiers and suppliers". In relation to appropriate risk allocation, it was associated with most of the key stakeholders because, as pointed out by the interviewee E12, "these stakeholders must be concerned about inconsistencies and failures in risk allocation".

The commitment between the partners concerns the concessionaire, because, as explained by the interviewee E14, "if the company is not committed, there is no 
need to talk about partnership". Considering that the commitment must be mutual, this factor was attributed to the public agencies that celebrate the PPP (Navy and Army) contract.

The previous analysis of costs and benefits was connected to the Ministry of Planning and the Navy, due to the role of these players in the project's economic feasibility. In this sense, as pointed out by the interviewee E8, "certainly the decisions of the Navy taken with or without adherence to the studies carried out end up compromising or making feasible the project".

Finally, the existence of a favorable economic environment was associated with the Ministries of Finance and Planning due the role of these stakeholders in the implementation of economic policy.

The identification of the critical factors associated with such stakeholders allows us to understand the importance conferred to them according to an analysis made from a theoretical perspective by Mitchell et al. (1997). The Army is a definitive stakeholder because it is associated with factors that give it power, legitimacy and urgency. Thus, these attributes appear to result from this player's association with factors such as political interest. Regarding this issue, attention should be drawn to aspects related to the project's alignment with federal government policy. Such engagement provides what Mitchell et al. (1997) call urgency in meeting interest and the power to influence the PPP structuring process.

The project's alignment with federal government policy enables the attribute of legitimacy, as an adaptation to of Mitchell et al. (1997)'s concept: a PPP contributes to the perception that the project is an consistent action with public interest (socially constructed system of norms, values, beliefs and definitions). Power also stems from the role played by the Army in the preparation of the contract according to its own interests. This player also has the power to influence the project because of its association with the project's quality factor, given that it is responsible, among other things, for defining the project's scope and criteria used to select the private partner.

The Ministry of Planning is also a definitive stakeholder, which seems to result from its association with: $(A)$ the institutional apparatus (power) because this Ministry has a PPP unit dedicated to structuring the project; (B) adequate regulatory framework (power) that it helped draft and is able to change; (C) favorable economic environment (power), since it can provide funds for PPPs of federal entities; (D) budgetary restrictions (power), as it controls the federal budget (urgency); and (E) political interest (legitimacy), as it is part of the PMC. This result is related to that found by Palovita and Aho (2010), who claim that public policy makers can be considered definitive stakeholders. 
The Ministry of Finance is a dominant stakeholder, which seems to result from its association with: (1) the favorable economic environment (power), as a result of its influence on the availability of financial resources that are earmarked for financing lines; (2) regulatory framework (power), which relates to guarantees to PPPs; (3) budgetary restrictions (power); and (4) political interest (legitimacy), as a member of the PMC. This result is related to that found by Gomes (2004), who claim that public policy makers can be considered the most important stakeholders.

The Navy is a dominant stakeholder, which seems to result from its association with: (I) the institutional apparatus (power), since it has multidisciplinary experts who provide their thoughts on the project; (II) political interest (legitimacy), due to the commitment of the top tier of naval administration, which provides the power to influence the structuring process; and (III) project quality and drafting of the contract (power), because as public partner it can establish the scope and selection criteria for the private partner. These results can be seen on Figure 6 .

\section{Figure 6 - Connections identified}

\begin{tabular}{|c|c|c|c|c|c|}
\hline \multirow{2}{*}{\multicolumn{2}{|c|}{ Critical Factor }} & \multicolumn{4}{|c|}{ Stakeholder } \\
\hline & & Army & Navy & $\begin{array}{l}\text { M. } \\
\text { Planning }\end{array}$ & \multirow{2}{*}{$\begin{array}{l}\text { M. } \\
\text { Finance } \\
\qquad x\end{array}$} \\
\hline \multirow{12}{*}{ 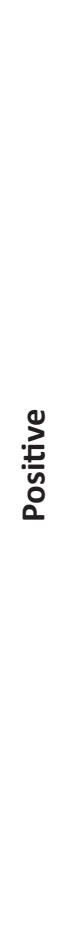 } & Political interest & $x$ & $x$ & $x$ & \\
\hline & Institutional apparatus & $x$ & $x$ & $x$ & \\
\hline & Project Quality & $x$ & $x$ & $x$ & $x$ \\
\hline & Adequate regulatory framework & & & $x$ & $x$ \\
\hline & Entrepreneurial culture with PPP & $x$ & $x$ & $x$ & $x$ \\
\hline & $\begin{array}{l}\text { Commitment between the } \\
\text { partners }\end{array}$ & $x$ & $x$ & & \\
\hline & Favorable economic environment & & & $x$ & $x$ \\
\hline & Appropriate risk allocation & $x$ & $x$ & $x$ & \\
\hline & Prior analysis of costs and benefits & & $x$ & $x$ & \\
\hline & $\begin{array}{l}\text { Compliance with } \\
\text { recommendations of oversight } \\
\text { bodies }\end{array}$ & $x$ & $x$ & & \\
\hline & $\begin{array}{l}\text { Compatibility between the } \\
\text { partners' expectations }\end{array}$ & $\mathrm{x}$ & $\mathrm{x}$ & $x$ & \\
\hline & Well-drafted contract & $x$ & $x$ & $x$ & $x$ \\
\hline
\end{tabular}




\begin{tabular}{|c|c|c|c|c|c|}
\hline \multirow{2}{*}{\multicolumn{2}{|c|}{ Critical Factor }} & \multicolumn{4}{|c|}{ Stakeholder } \\
\hline & & Army & Navy & $\begin{array}{l}\text { M. } \\
\text { Planning }\end{array}$ & $\begin{array}{l}\text { M. } \\
\text { Finance }\end{array}$ \\
\hline \multirow{3}{*}{ 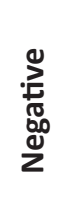 } & Environmental restrictions & $x$ & $x$ & $x$ & \\
\hline & Budgetary restrictions & & & $x$ & $x$ \\
\hline & $\begin{array}{l}\text { Lack of competitive bidding } \\
\text { process }\end{array}$ & $x$ & $x$ & $x$ & \\
\hline
\end{tabular}

Source: Authors.

The use of the Frooman (1999) framework revealed that some of the most influential stakeholders are also the most powerful (Navy, Army, Ministry of Planning and Ministry of Finance). Thus, there seems to be an association between influence and the power attribute because the stakeholder is able to influence an organization when it has, among other factors, "control over resources, over technical skills, and power resulting from legal prerogatives" (GOMES, 2004, p. 47).

Our results show that most stakeholders influence and are influenced by the PPP structuring process actors (Ministry of Planning, Ministry of Finance, Chief of Staff, Army, Navy and others), which highlights the mutual dependence between these stakeholders and the PPP structuring process. The PMC, consultants, oversight bodies and the UNDP were classified as stakeholders that only influence PPP structuring. In this situation, the stakeholder has an influence on the process, but does not depend on it or suffer its influence, which seems to be a scenario where power lies with the stakeholder.

Finally, we have identified users, local society, suppliers and the concessionaire as stakeholders who are only influenced by that structuring process. This scenario is called power of the firm, in this case, the public organization. A summary of these results is presented in Figure 7. 
Figure 7 - Relationship of influence between stakeholders and structuring of the PPPs

Does the PPP structuring
process influence
stakeholders?

Do stakeholders influence the PPP structuring process?

No Yes

Power of the Organization

Low interdependence

Power of the

Stakeholder

Yes

PMC, consultants, oversight bodies and UNDP users, local community, suppliers and concessionaire

High interdependence

Ministry of Planning, Ministry of Finance, Chief of Staff, Army, Navy, Financiers, Media and Local Public Bodies

Source: authors based on Frooman (1999).

In summary, the results demonstrate that a new actor (UNDP) and one new critical success factor (compliance with the recommendations of oversight bodies) were identified. Furthermore, when comparing our results about stakeholders according to Mitchell et al. (1997)'s model and those that have influence over the company (Frooman (1999)'s framework), we find that some of the most influential stakeholders are also the most powerful (Navy, Army, Ministry of Planning and Ministry of Finance).

\section{Conclusions}

The present study aimed to identify the relationship between stakeholders and critical success factors in the Brazilian Government PPPs in order to contribute to the literature gap, since the literature researched in different bases found no studies addressing the two issues connectedly, CSF and stakeholders. Thus, this study makes the connection between them. The joint analysis of the two constructs also allows a contribution to Stakeholder Theory because the critical factors associated with the actors show how the action of these actors can affect the development of a PPP.

Stakeholders and CSFs were identified and compared with those described in the literature. In this sense, this work contributes to the theoretical body about PPP stakeholders because we identified a new actor (UNDP) that has not been found in priors studies. In the same sense, about the critical factors, this study's contribution 
is to draw attention to a new one that has not been pointed out by the literature consulted: compliance with the recommendations of oversight bodies. Besides, the stakeholders and CSFs were connected according the reasons for the connections appointed by the informants.

In addition to identifying the stakeholders and critical factors, we also have verified the influence power of such players. In this sense, the majority of interviewees chose as the most influential the public bodies of the federal government responsible for structuring, namely, Navy, Army and Ministries of Planning and Finance, which corroborates previous studies such as those of Gomes (2004).

Furthermore, the results about stakeholders identification according to Mitchell et al. (1997)'s and Frooman (1999)'s models show that it is possible to connect these two classifications. So, the models we have used are complementary since some of the most influential stakeholders are also the most powerful. This study also reinforces the applicability of the Freeman and Reed (1983) seminal concept of stakeholder, but as an addition (influences and is influenced) and not as an exclusion (influences or is influenced).

We have noted, however, that this study is subject to the inherent limits to qualitative research approach that uses interviews to data collection. We also have noted that our study's inferences should not be generalized, because it is a case study about the two first PPP of the military forces that were more advanced in the moment of realization of the research. Thus, it is not possible to extend our results and conclusions to all PPPs in Brazil, even though it is possible do draw some lessons on the subject. It was not possible to investigate a greater number of cases due to the researchers' resource limit.

In addition, our study observed stakeholders and critical factors related to the structuring process. Therefore, the results cannot be extended to the phases of PPP management because such phases occur after the structuring process. Given the above, one of the recommendations for future research is to apply the same methodology with stakeholders related to the post-structuring phase (PPP management).

Finally, we also recommend to enlarge the sample of PPPs analyzed, i.e., to apply the same methodology, but to research the structuring of state and municipal PPPs. That way, one can develop a comparative study with a view to developing inputs for later generalization. In addition, considering that there are other stakeholder identification and categorization models, we recommend to apply the methodology using other models, enriching this approach in the study of PPPs and allowing comparing the explanatory power of each model. 


\section{References}

Azevedo, D.; Azevedo, P. F. Nem muita folga, nem muito aperto: a relação entre restrição fiscal e parcerias público-privadas. In: EnANPAD, 2017, São Paulo. Anais do EnANPAD 2017. Rio de Janeiro: ANPAD, 2017. v. 1. p. 1-22.

BRIto, B. M. B.; SilveirA, A. H. P. Parceria público-privada: compreendendo o modelo brasileiro. Revista do Serviço Público, v. 56, n. 1, p. 7-21, 2005.

Bueno, R. L. P.; BrelÀz, G.; SAlinas, N. S. C. Administração pública brasileira no século 21: seis grandes desafios. Revista do Serviço Público, v. 67, edição especial, p. 7-28, 2016.

CABRAL, S.; Fernandes, A.; RIBEIRo, D. Os Papéis dos Stakeholders na Implementação das Parcerias Público-Privadas no Estado da Bahia. Cadernos EBAPE.BR, v. 14, n. 2, p. 325-339, 2016.

CABRAL, S.; REIS, C. J. O. Parcerias público-privadas em megaeventos esportivos: um estudo comparativo da provisão de arenas esportivas para a Copa do Mundo Fifa Brasil 2014. Revista de Administração Pública, v. 51, n. 4, p. 551-579, 2017.

CASTRO, M.; Bulgacov, S.; HoffMANN, V. E. Relacionamentos Interorganizacionais e Resultados: Estudo em uma Rede de Cooperação Horizontal da Região Central do Paraná. Revista de Administração Contemporânea, v. 15, n. 1, p. 25-46, 2011.

CAvalcante, P. L. Trends in Public Administration after Hegemony of the New Public Management: a literature review. Revista do Serviço Público, v. 70, n. 2, p. 195-218, 2019.

CUTRIM, S.; TRISTÃo, J.A.M.; TRISTÃO, V.T.V. Aplicação do Método Delphi para Identificação e Avaliação dos Fatores Restritivos à Realização de Parcerias PúblicoPrivadas. Revista Espacios, v. 38, n. 22, p. 29-43, 2017.

Falqueto, J.; HoffmanN, V. E.; Gomes, R. C. A influência dos stakeholders na implantação do planejamento estratégico em uma instituição pública de ensino superior. In: XXXVII Encontro dA ASSOCIAÇÃO NACIONAL DE PÓS-GRADUAÇÃO E PESQUISA EM Administração - enANPAD, Rio de Janeiro, p. 1-16, 2013.

Firmino, S. I. Fatores Críticos de Sucesso das Parcerias Público-Privadas: Aspetos Político-Institucionais. Estudo de Caso das Rodovias em Portugal. Revista de Administração Pública, v. 52, n. 6, p. 1270-1281, 2018.

FRANCO, M. J. B. Tipologia de processos de cooperação empresarial: uma investigação empírica sobre o caso português. Revista de Administração Contemporânea, v. 11, n. 3, p. 149-176, 2007.

Freeman, R. E.; Reed, D. L. Stockholdres and Stakeholders: a new perspective on corporate governance. California Management Review, v. 25, n. 3, p. 88-106, 1983.

Freeman, R. E. Strategic Management: A Stakeholder Approach, Massachusetts, Pitman, 1984

Frooman, J. Stakeholder influence strategics. Academy of Management Review, v. 24, n. 2, p. 191-205, 1999.

GOMES, R. C. Who are the relevant stakeholders to the local government context? 
Empirical evidences on environmental influences in the decision-making process of English local authorities. Brazilian Administration Review, v. 1, n. 1, p. 34-52, 2004. Hodge, G; Greve, C. Public - Private Partnerships: An International Performance Review. Public Administration Review. v. 67, p. 545-558, 2007.

HWANG, B. G.; ZHAO, X.; GAY, M. J. S. Public private partnership projects in Singapore: Factors, critical risks and preferred risk allocation from the perspective of contractors. International Journal of Project Management, v. 31, p. 424-433, 2013.

ISMAIL, S. Critical success factors of public private partnership (PPP) implementation in Malaysia. Asia-Pacific Journal of Business Administration, v. 5, n.1, p. 6-19, 2013. JACOBSON, C.; CHOI, S. Success factors: public works and public-private partnerships, International Journal of Public Sector Management, v. 21, n. 6, p. 637 - 657, 2008.

JAMALI, D. A public private partnership in the Lebanese telecommunications industry: critical success factors and policy lessons. Public works Management Policy, v. 9, p.103-119, 2004.

JARILLO, J. C. On strategic networks. Strategic Management Journal, v. 9, n. 1, p. 3141, 1988.

JeRger, E. Parcerias público-privado. Revista do Serviço Público, v. 120, n.1, p. 165179, 1996.

KYEI, R. O.; CHAN, A. P. C. Review of studies on the Critical Success Factors for PublicPrivate Partnership projects from 1990 to 2013. International Journal of Project Management, v. 33, p. 1335-1346, 2015.

LIU, T.; WILKINSON, S. Using public-private partnerships for the building and management of school assets and services. Engineering, Construction and Architectural Management, v. 21, n. 2, p. 206 - 223, 2014.

LIU, T.; WANG, Y.; WILKINSON, S. Identifying critical factors affecting the effectiveness and efficiency of tendering processes in public-private partnerships: a comparative analysis of Australia and China. International Journal of Project Management, v. 34, p. 701-716, 2016.

MASKIN, E.; TIROLE, J. Public-Private Partnerships and Government Spending Limits. International Journal of Industrial Organization, v. 26, n. 2, p. 412-420, 2008.

MÁxIMO, L. PPPs têm recorde de projetos, mas apenas três avançam. Disponível em: <https://www.valor.com.br/brasil/5239665/ppps-tem-recorde-de-projetosmas-apenas-tres-avancam>. Acesso em: 15 fev. 2019.

MITCHELL, R. K.; AGLE, B. R.; WOOD, D. J. Toward a theory of stakeholder identification and salience: defining the principle of the who and what really counts. Academy of Management Review, v. 22, n. 4, p. 853-886, 1997.

mORAES, m. s.; TAGLE, G. R. Os impactos fiscais dos contratos de parceria públicoprivada. Estudo de caso do ambiente institucional e da prática no Brasil. Banco Interamericano de Desenvolvimento. Nota Técnica $n^{\circ}$ IDB-TN-1246, 2017. Disponível em: <https://publications.iadb.org/pt/publication/os-impactos-fiscaisdos-contratos-de-parceria-publico-privada-estudo-de-caso-do>. Acesso em: 05 ago. 2019. 
NORTH. D. Institutions. Journal of Economic Perspectives, v. 5, n. 1, p. 97-112, 1991. Nose, M. Enforcing Public-Private Partnership Contract: How do Fiscal Institutions Matter? International Monetary Fund. IMF Working Papers $n^{\circ}$ WP/17/243, 2017. Disponível em: <https://www.imf.org/en/Publications/WP/Issues/2017/11/15/ Enforcing-Public-Private-Partnership-Contract-How-do-Fiscal-InstitutionsMatter-45353>. Acesso em: 05 ago. 2019.

OLIVER, C. Determinants of interorganizational relationships: Integration and future directions. The Academy of Management Review, v. 15, n. 2, p. 241-265, 1990.

PALOVITTA, A.; AHO, V. Recognizing definitive stakeholders in corporate environmental management. Management Research Review, v. 33, n. 4, p. 306-316, 2010.

PONGSIRI, N. Regulation and public-private partnerships. International Journal of Public Sector Management, v.15, n. 6, p. 487 - 495, 2002.

POWELL, W. W. Neither market nor hierarchy: networks forms of organization. Research of Organizational Behaviour, v. 12, p. 295-336, 1990.

Queiroz, C.; Astesiano, G.; Serebrisky, T. An Overview of the Brazilian PPP Experience from a Stakeholders' Viewpoint. Inter-American Development Bank. Technical note $\mathrm{n}^{\circ}$ IDB- TN- 641, 2014. Disponível em: <http://publications.iadb.org/ handle/11319/6399?locale-attribute=en>. Acesso em: 11 jul. 2019.

RODRIGUES, B.; ZUCCO, C. Uma comparação direta do desempenho de uma PPP com o modelo tradicional de contratação pública. Revista de Administração Pública, v. 52, n. 6, p. 1237-1257, 2018.

SILVA, C. M.; COSER, C. Rede de Relações Interorganizacionais no Campo Organizacional de Videira - SC. Revista de Administração Contemporânea, v. 10, n. 4, p. 9-45, 2006.

WEgneR, D.; PADULA, A. D. Quando a cooperação falha: um estudo de caso sobre o fracasso de uma rede interorganizacional. Revista de Administração Mackenzie. v. 13, n. 1, p. 145-171, 2012.

WeIERMAIR, K.; Peters, M.; FREHSE, J. Success factors for public private partnership: cases in Alpine Tourism development. Journal of Services Research, Special Issue, p. 7-21, 2008.

SABRY, M. I. Good governance, institutions and performance of public private partnerships. International Journal of Public Sector Management, v. 28, n. 7, p. 566 $-582,2015$.

SCHEPPER, S.; DOOMS, M.; HAEZENDONCK, E. Stakeholder dynamics and responsibilities in public private partnerships: a mixed experience. International Journal of Project Management, v. 32, n. 7, p. 1210-1222, 2014.

THAMER, R.; LAZZARINI, S. Projetos de parceria público-privada: fatores que influenciam o avanço dessas iniciativas. Revista de Administração Pública, v. 49, n. 4, p. 819-846, 2015. 


\section{David Curtinaz Menezes}

Universidade de Brasília (UnB). Graduado em Direito pela Universidade Salvador e em Ciências Econômicas pela Universidade Federal da Bahia. Mestre em Administração pela Universidade de Brasília.

\section{Valmir Emil Hoffmann}

Universidade de Brasília (UnB)

Doutor em Administração de Empresas pela Universidad de Zaragoza, Espanha.

Diretor Científico da Associação Nacional de Pós-Graduação e Pesquisa em Administração.

\section{Helio Zanquetto Filho}

Universidade Federal do Espírito Santo (EFES).

Doutor em Engenharia de Produção pela Pontifícia Universidade Católica do Rio de Janeiro.

Professor Efetivo (Associado) da Universidade Federal do Espírito Santo 